\title{
Dealing with bioethical dilemmas: A survey and analysis of responses from ministers in the Reformed Churches in South Africa
}

\begin{abstract}
Author:
Magdalena (Leentie) C. de Lange ${ }^{1}$

Affiliation:

${ }^{1}$ Faculty of Theology,

North-West University,

Potchefstroom Campus,

South Africa

Note:

Shortly after completing this article, Dr Leentie de Lange passed away after a long and courageous battle with cancer lasting fourteen and a half years.
\end{abstract}

Correspondence to:

Andries van Aarde

Email:

editor@hts.org.za

\section{Postal address:}

University of Pretoria, Faculty of Theology, Private Bag X20, Lynnwood Road, Hatfield 0083, Pretoria, South Africa

Dates:

Received: 01 June 2010

Accepted: 21 Aug. 2010

Published: 08 Feb. 2012

How to cite this article: De Lange, M.C., 2012, 'Dealing with bioethical dilemmas: A survey and analysis of responses from ministers in the Reformed Churches in South Africa', HTS Teologiese Studies/ Theological Studies 68(1), Art. \#882, 10 pages. http:// dx.doi.org/10.4102/hts. v68i1.882
C 2012. The Authors. Licensee: AOSIS OpenJournals. This work is licensed under the Creative Commons Attribution License.
Recent technological advancements in Bioethics have been rapid and incremental, leaving little time for Christian ethicists to reflect or develop a coherent methodological approach. To assess the situation in the Reformed Churches in South Africa (RCSA), a bioethical questionnaire was developed and administered during the synod in 2009. Three practical questions served as point of departure, viz. which bioethical issues confronted ministers in their work environment, which value judgement trends are evident when counselling members of their congregations and what theoretical frameworks or resources do they call upon when reflecting on these difficult situations? The survey consisted of 19 questions with several subquestions that sought demographic information to determine the population and information about bioethical issues confronting them, methodological strategies they apply and how they think they can contribute to the resolution of any such bioethical dilemmas. The results were tabulated and it was concluded that recent advancements in biotechnology cannot be ignored or dealt with in a piecemeal fashion any longer, either by the RCSA or its ministers. The need for clarity and analysis of the principles underlying those theories that guide or should guide their decision-making and pastoral care in dealing with bioethical dilemmas was emphasised. The findings highlighted the need for appropriate courses in Bioethics to be taught during initial theological training, as well as the need to keep the debate alive by offering workshops, seminars and short courses for practicing ministers to enhance awareness and allay fears and uncertainties in this very dynamic and morally challenging field of human and scientific endeavour.

\section{Introduction}

New and sometimes revolutionary and controversial developments in the biomedical sciences, reproductive technologies, medical genetics and biotechnology in the Life Sciences have occurred rapidly in recent times. This has resulted in ethical problems being 'downloaded' on the public in unprecedented ways, creating a situation in which 'technology outpaces morality' (ColeTurner 2006:929; De Roubaix 2002:9). The impact of issues such as abortion, stem cell research, in vitro fertilisation, surrogate motherhood, life-support systems, dialyses, organ transplants, reproductive techniques, modern contraceptives, prenatal testing and environmental problems has been that these are no longer only perceived to be 'somewhere-out-there', but have become part of the life and conversation of everyday society. More specifically, these technological advancements in the field of Bioethics have been so rapid and incremental that it has left little time for Christian ethicists to reflect upon or to develop a coherent methodological approach (Gushee 2003:1; Gustafson 1983).

Ministers in the active church ministry are increasingly involved in providing spiritual and moral guidance relating to this new knowledge and technologies. This has brought about additional challenges for Christian traditions when trying to give answers to new questions, new options, new choices and radically challenging the metaphysical and religious approach to fundamental questions such as, amongst others, the status of the embryo:

The new technologies also allow us to prolong lives that would otherwise quickly perish. They make us question the value of human life when the quality of life is faltering. They confront us with the questions of whether some unborn lives ought to be cut short because they might not be worth living. Our new technologies raise questions about the value of the human life both in the early and in its later stages. (Sutton 2008:2)

Through technological development in all these different spheres, such questions have become both more prevalent and significant for ministers as well. Already in 1981, pastoral counsellor John C. Fletcher believed that the opportunities the clergy have in using information related to all these challenging questions were indeed plentiful (Fletcher 1981:22; cf. also Mertens, Hendrix 
\& Gordon 1986:45). Many years later, Hanford (2006:178, 181) still challenges American clergy to interpret the Gospel along with Bioethics in order to be competent in dealing with decision-making. This consultation process not only builds on biblical principles, but is also a 'complex form of human interaction, of interpretation, of balance between values and identity of parents, families, professional institutions, and culture' (Thomasma 2001:46).

As part of a doctoral study in Ethics in the Faculty of Theology at the Potchefstroom Campus of North-West University (NWU) on the interdisciplinary relation between Bioethics, Theology, Philosophy and the Life Sciences (De Lange 2009), the author surveyed ministers in the Reformed Churches in South Africa (RCSA) in order to determine what actually happens in their practices in the area of bioethical counselling. ${ }^{1}$ On the basis of data collected in various literature surveys, there is no evidence in the South African context that such a study has been conducted before. It has been pointed out that in the American context, the clergy were not properly prepared to deal with this new knowledge and technological advancements. In another recent publication concerning the child sex abuse scandal and crisis in the Catholic Church, Keenan (2005:117) comes to the conclusion that the Church needs to develop programmes that instruct pastors on the multitudinous ethical issues that are part of everyday ecclesial life.

For the purpose of this research project, Bioethics was defined broadly to include ethical questions not only related to medical aspects, but also to agricultural and environmental problems - in other words, our relationship with created reality. In the past, Bioethics was narrowly linked to traditional medical ethics; broadening its definition results in the integration of reflections on new developments in biotechnology which, as Schotsmans (2009:1) argues, 'go beyond narrowly curative concerns.'

Against the background of this contextual framework, the purpose of this part of the study was twofold, namely, (1) to conduct a comprehensive literature review on bioethical issues that arise in relation to data analysis and (2) to develop a survey, the 'Bioethics questionnaire' ${ }^{2}$, with which to assess bioethical issues that arise during counselling sessions between ministers and congregation members.

Formulating this more pointedly, three practical questions serve as a point of departure, viz.:

- Which bioethical dilemmas do ministers in the RCSA encounter in their work environment and how often are they confronted with these dilemmas?

- Which value judgements do they make when reflecting on bioethical dilemmas?

- Which theoretical and/or theological sources or resources do they call upon and how do they reflect on these difficult situations when counselling members of their congregation on bioethical dilemmas?

1.The focus falls on the RCSA because the author lectured in the Faculty of Theology associated with this specific denomination.

2.The questionnaire was to be published in the final version of the thesis.
The hypothesis is that those who have studied at the Theological Seminary of Potchefstroom, and other affiliated divinity schools (past and present), have not had the type of bioethical training (i.e. how to deal with aspects such as reasoning, insights, norms, cultural needs, demands of confidentiality, the principle of subsidiary, the just treatment of those who come for guidance, decision-making strategies, etc.) that they require to deal adequately with these issues in ecclesiastical life. The study aims to prove that the RCSA needs to provide this training through the development of programmes that not only instruct ministers, but empowers them with both theological and ethical principles as well as concrete knowledge of the multitudinous ethical issues that are part of everyday ecclesial life and which will become even more prevalent during the course of the 21st century.

\section{Methodology}

It is important to motivate my reasons for employing an empirical research strategy as it is not always a popular choice within the bioethical research community. The initial antagonism towards empirical research in Bioethics stems not only from the worry that empirical approaches waiver on the fact or value distinction, but also the normative mandate that still maintains the field. This antagonism is only beginning to subside (Borry, Schotman \& Dierickx 2005; Goldenberg 2005). In an earlier article, Borry et al. (2004) argue for the positive role empirical research can play in bioethical reflection and decision-making (cf. Thomasma 1985:313). Borry et al. (2004:50) indicate that empirical research can contribute to every step in ethical reflection, viz. describing the moral question, in assessing the moral question and in evaluating the decision-making process. It is important to take into consideration that 'empirical data as such cannot generate normativity or determine what is good or evil, right or wrong' (Borry et al. 2004:51). Therefore, as a secondary aim, the article will show that the value of this empirical study lies primarily in testing the insights and findings of other researchers against praxis, which, in turn, can then generate new knowledge, collect valuable data on bioethical problems that ministers are confronted with in their pastoral roles (cf. McMinn \& Runner 2004), test theoretical frameworks and provide answers to difficult bioethical problems.

The study involved several phases:

- A comprehensive literature review was conducted to identify areas of interest in order to construct the questionnaire. This automated search, using keywords or combinations of keywords such as 'bioethics, statistics and ethics, ministers/clergy and bioethics, empirical research, questionnaire, etc.', identified a substantial amount of articles primarily covered in journals and textbooks which addressed, in some manner, key areas of Bioethics related to the research question and data analysis.

- A preliminary questionnaire was developed, entitled the 'Bioethics Questionnaire'.

- This questionnaire was then assessed, both qualitatively and quantitatively. 
- A pilot test was conducted. A pilot study is useful in identifying weak and strong points of the instrument, the effectiveness of the research questions, and to bring changes on where necessary (Breakwell 2003:242-243; Burns \& Grove 1997:52; Holloway 1997:121; Rosnow \& Rosenthal 1996:110-112, 206-207).

- The questionnaire was then administered during the RSCA synod in June 2009.

- The gathered data were analysed.

- Conclusions were drawn from the statistical results obtained.

\section{Instrumentation}

The questionnaire was constructed in line with the findings of the comprehensive literature survey, the theoretical framework for the research project and the research aims. The questionnaire items were developed to include responses to demography (Neuman 1994:293), general information on bioethical issues, and responses in relation to epistemological and theoretical frameworks in bioethical decision-making. A closed form format for certain questions was used to facilitate attentive and committed participation for the purpose of quantification and analysis of responses, as closed form questions meaningfully ascertain the frequency and degree of the phenomenon under investigation (De Vos et al. 2005:174).

Clear distinctions were made between empirical questions (i.e. 'What is the case?'), descriptive questions ('How many? How often?'), meta-analytical questions ('What is the state of the art regarding $x$ ? What are the key debates in domain $x$ ? What are the leading positions or paradigms?'), theoretical questions ('What are the most plausible theories for model $x$ ? What are the most widely accepted models, definitions or theories of $x$ ? Which are the most convincing explanations of $x$ ? What do competing theories say about $x$ ?'), and philosophical/normative questions ('What is the ideal profile of $x$ ? What is meant by $x$, etc?') (Babbie \& Mouton 2001:76-77, [author's own emphasis]).

As the synod of the RCSA included both speakers of Afrikaans and other languages, the questionnaire was compiled in two national languages, viz. Afrikaans and English. Participants could complete the questionnaire according to their language preference. The accompanying letter explained the context of the research, assured the participants of the confidentiality of their responses and clearly stated that anonymous participation gives the researcher permission to report the data in a publication.

The survey consisted of 19 questions with several subquestions that sought not only demographic information, but also information on bioethical issues with which the respondents are confronted and methodological strategies they apply. One open-ended question was included in an attempt to establish what the respondents think they can contribute to the resolution of bioethical dilemmas. They then had a choice to indicate whether they were available for interviews if necessary.

\section{Population}

The data reported in this article are based on a studypopulation of 100 ministers ordained in the RCSA. During this time, there were 295 practicing ministers in the RCSA (Gereformeerde Kerke in Suid-Afrika 2009:10-15). As no woman may currently be ordained in the RCSA, the population consisted only of men from several ethnic groups and language preferences in South Africa (Table 1).

The congregations in which the respondents work were identified to lie within the following demographic areas: towns and rural areas (50\%), cities (43\%), deep rural areas $(6 \%)$. This demographic profile could provide an indication of the nature and frequency of bioethical dilemmas with which these ministers are confronted.

The respondents have served an average of 21 years (ranging from 1 to 39 years) in the ministry. PhD degrees are held by $18 \%$ of the respondents, whilst $33 \%$ hold Masters degrees and a total of $45 \%$ hold post-secondary education such as Bachelors and Honours degrees. These data provide a profile of a population of professional ministers who are well educated and established in their ministering careers.

When asked about the ethics-related training they have received, $65 \%$ indicated that they learned to perform bioethics consultation independently, without any formal training or direct supervision. Twenty-two percent of the respondents indicated that they have received no training whatsoever, or that they did a general Ethics course in their training. Reading books and journals was the most popular way (49\%) to continue their education about bioethical issues and update their knowledge in the last two years. Consulting the Internet $(23 \%)$, attending conferences $(5 \%)$, attending workshops $(7 \%)$ and Church-related education (22\%) were also reported. Thirty-one percent of the respondents indicated that they have not done anything to improve their knowledge on bioethical dilemmas. Only $6 \%$ of the respondents are involved in ethics committees.

It seems that there is lack of interest in asking ministers to be involved in discussions of a bioethical nature, as 36\% of them indicated that they are not asked to take part in any discussions. Eighteen percent of the respondents identified a lack of knowledge about how to get involved in these discussions. The fact that $61 \%$ indicated no awareness of any formalisation of a position statement from the RCSA on bioethical issues created by application of biotechnological advances is significant.

TABLE 1: The spread of languages amongst the questionnaire respondents at the Reformed Churches in South Africa synod, June 2009.

\begin{tabular}{ll}
\hline Language & $\mathbf{\%}$ \\
\hline Afrikaans & 87.80 \\
Setswana & 4.07 \\
Tshivenda & 3.06 \\
English & 3.05 \\
Sesotho & 1.02 \\
Xitsonga & 1.02 \\
Other (French congregation) & 1.00 \\
\hline
\end{tabular}


Only 21\% indicated that they have been asked by congregation members to assist them in making decisions about bioethical issues. Reasons for this low figure can differ over a wide spectrum of answers and needs to be investigated further. Developers of curricula must take into consideration the fact that only $54 \%$ of minsters indicated that their training prepared them to understand the nature of the crises shared with them in hospital rooms, long-term care facilities and during consultations.

\section{Procedures}

\section{Ethical considerations}

The problems associated with questionnaire-based research and the ethical validity thereof is dealt with in an article by Asai, Nakayama and Naito (2003). It underlines the importance of a true understanding of research ethics in emphasising ethical sensibility to promote the appropriate use of questionnaire research, and provides a useful profile on criteria for ethical validity standards. It is also important that research ethics are integrated into the research process in order to guarantee the research integrity of the project (Lategan 2008:116-117; cf. Lategan 2007:235-237). Experimental protocol was honoured in that permission and consultation to carry out the investigation was obtained from the Ethics Committee (Faculty of Theology, NWU, Potchefstroom Campus).

\section{Survey questionnaire development ${ }^{3}$}

In order to ensure the effective compilation of the various sections of questionnaire items, principles of questionnaire construction were adhered to (De Vos et al. 2005:170-175; Orr 1992:86-89; Thietart 2001:174-175). A draft questionnaire was compiled based on the following:

- A study of practical guidelines posited by numerous writers with regard to the compilation of questionnaires (Creswell 2003:153-171; Creswell \& Plano Clark 2007:123125; De Vos et al. 2005:160-163; Fox, Myers \& Pearlman 2007:14; Grosser 1999:129-135; Guba \& Lincoln 1989:611; Kumar 2005:115-142; Neuman 1997:142; Sudman \& Bradburn 1983; Taylor 1996; Wang, Katz \& Howard 2007).

- A literature survey on the main topic of the study, with particular reference to the epistemological and theologicalethical background against which ministers could guide congregation members in ethical decision-making and ethical issues relevant to the ministry (Cross 1977; Fry 2005; Grundstein-Amado 1991; Hanford 2006; Human \& Müller 2009; McMillan 1986; Seitz et al. 2004; Simmonds 1994).

The questionnaire and protocol for data collection were refined based on feedback from the survey respondents in a pilot test. The final instrument contained five sections dealing with 19 primary questions with sub-questions and one potential follow-up question. Most of the questions offered a choice between responses which could be marked by the respondent. Answers to the open-ended question will be indicated by categorising the most common responses.

\footnotetext{
3.Mrs Wilma Breytenbach from the Statistical Consultation Services (NWU Potchefstroom Campus) served as statistical advisor in the construction of the questionnaire.
}

The following factors were also taken into consideration:

Expert advice and elimination of procedural bias: To identify potentially unclear instructions and statements, quality assessment included the review and comments of the following experts: my two promoters, staff from Statistical Consultation Service (NWU, Potchefstroom Campus), two bioethicists (one at the University of Stellenbosch and one in private practice), one retired ethicist, one Afrikaans-speaking and one Sesotho-speaking professor in the Faculty of Theology at Potchefstroom who are still active in congregational work, and one expert in questionnaire development - all with a view to refining it.

Key guidelines during this phase were clarity, the avoidance of double-barrelled questions, ambiguity, the use of words with equivalent meanings in the Afrikaans and English statements, etcetera.

Validation and reliability: The validity and reliability of the questionnaire is increased by designing it in accordance with the standards and support of the scientific community. Following the work of Creswell and Plano Clark (2007:244), De Vos et al. (2005:167) and Neuman (1997:142), this was determined by a pilot test in which eight people took part.

The qualitative assessment included the review and comments not only of bioethics experts and statisticians; the evaluation involved their comments about wording, obvious content validity, as well as clarity. Quantitative assessment involved responses from 10 selected ministers (Afrikaans and English) - not only in the RSCA, but also of clergy of different denominations (ministers of the Dutch Reformed Church, the Reformed Church, and one Catholic priest). This assessment included understanding reading level, responsiveness of the formatting, font size, sequence of the questions and questions that may be confusing to the respondent (Sugerman \& Sulmassy 2001:201-202). Final clearance was also obtained by an accredited translator.

\section{Data collection}

The questionnaire was handed out at the synod meeting of the RCSA in June 2009 in Potchefstroom and some were posted. Collection took place at Potchefstroom and those who chose to submit their questionnaires at a later stage were provided with self-addressed envelopes, after which the questionnaires were returned by mail.

\section{Statistical analysis ${ }^{4}$}

Statistical analysis is a dynamic discipline that provides methods that can be of great help to solve problems in divergent contexts. Survey research also plays an important role to gain insight into the preferred goal orientation and focus of the research topic (cf. Steyn et al. 2000).

Data from the questionnaire were statistically converted by using the SAS statistical computer package (SAS Institute Inc.

4.Prof. Faans Steyn from the Statistical Consultation Service (NWU, Potchefstroom campus) assisted in analysing and interpreting the data. 
2003). Descriptive statistics were used in the analysis phase of the project. This entails the ordering and summarising of data by means of tables and graphic representation (of the data) and the calculation of descriptive measures of inherent tendencies. The characteristics of the observed data are highlighted particularly well by this procedure.

\section{Results}

Section A of the questionnaire dealt with demographic information, as reported in Table 1 and the 'Population' subsection above.

5.Please note that missing frequencies are not reported in the results (Field 2005:5354). Statistical significant differences are dealt with in the discussion.

\section{Questionnaire Section B}

Section B dealt with ethical issues with which ministers were confronted with during the last five years (Tables 2, 3 and 4).

\section{Questionnaire Section C}

In Section $\mathrm{C}$ of the questionnaire, I tried to come to an understanding of the ministers' value-judgement tendencies by simply asking them to respond either 'yes' or 'no' to a list of questions and statements (Table 5).

\section{Questionnaire Section D}

In Section $\mathrm{D}$, the ministers were asked to reflect on the view of pastoral moral leadership by indicating if they 'disagree

TABLE 2: The frequency with which ministers were confronted with ethical issues regarding reproductive technologies and pregnancy.

\begin{tabular}{|c|c|c|c|c|c|c|c|c|c|}
\hline & \multicolumn{2}{|c|}{ Never } & \multicolumn{2}{|c|}{ Seldom } & \multicolumn{2}{|c|}{ Sometimes } & \multicolumn{2}{|c|}{ Frequently } \\
\hline \multicolumn{2}{|c|}{ Reproductive technologies } & \multirow{2}{*}{$\frac{f}{52}$} & \multirow{2}{*}{$\begin{array}{c}\% \\
53.06\end{array}$} & \multirow{2}{*}{$\frac{f}{26}$} & \multirow{2}{*}{$\begin{array}{c}\% \\
26.53\end{array}$} & \multirow{2}{*}{$\frac{f}{20}$} & \multirow{2}{*}{$\frac{\mathbf{\%}}{20.41}$} & \multirow{2}{*}{$\begin{array}{l}f \\
0\end{array}$} & \multirow{2}{*}{$\begin{array}{c}\% \\
0\end{array}$} \\
\hline 1. & Abortion because of unwanted pregnancy & & & & & & & & \\
\hline 2. & Abortion because of medical reasons & 52 & 52.53 & 28 & 28.28 & 19 & 19.19 & 0 & 0 \\
\hline 4. & Use of embryos in medical research & 80 & 81.63 & 16 & 16.33 & 2 & 2.04 & 0 & 0 \\
\hline 5. & Contraceptive issues & 40 & 40.82 & 23 & 23.47 & 26 & 26.53 & 9 & 9.18 \\
\hline 6. & Donor insemination (in the case of an unmarried woman) & 83 & 83.84 & 12 & 12.12 & 3 & 3.03 & 1 & 1.01 \\
\hline 8. & $\begin{array}{l}\text { Genetic testing of the foetus during the early stages of } \\
\text { pregnancy }\end{array}$ & 42 & 42.86 & 31 & 31.63 & 20 & 20.41 & 5 & 5.10 \\
\hline 9. & Moral status of the human embryo & 47 & 49.69 & 24 & 24.49 & 22 & 22.45 & 5 & 5.10 \\
\hline 10. & Choices regarding gender & 68 & 70.10 & 16 & 16.49 & 10 & 10.31 & 3 & 3.09 \\
\hline 11. & $\begin{array}{l}\text { Freezing of the umbilical cord as source of stem cells for } \\
\text { later use }\end{array}$ & 88 & 89.80 & 8 & 8.16 & 2 & 2.04 & 0 & 0 \\
\hline 12. & Surrogate pregnancy & 74 & 75.51 & 19 & 19.39 & 5 & 5.10 & 0 & 0 \\
\hline 13. & Other (please specify) & 26 & 89.86 & 2 & 6.90 & 1 & 3.45 & 0 & 0 \\
\hline
\end{tabular}

$f$, frequency.

TABLE 3: The frequency with which ministers were confronted with general medical issues

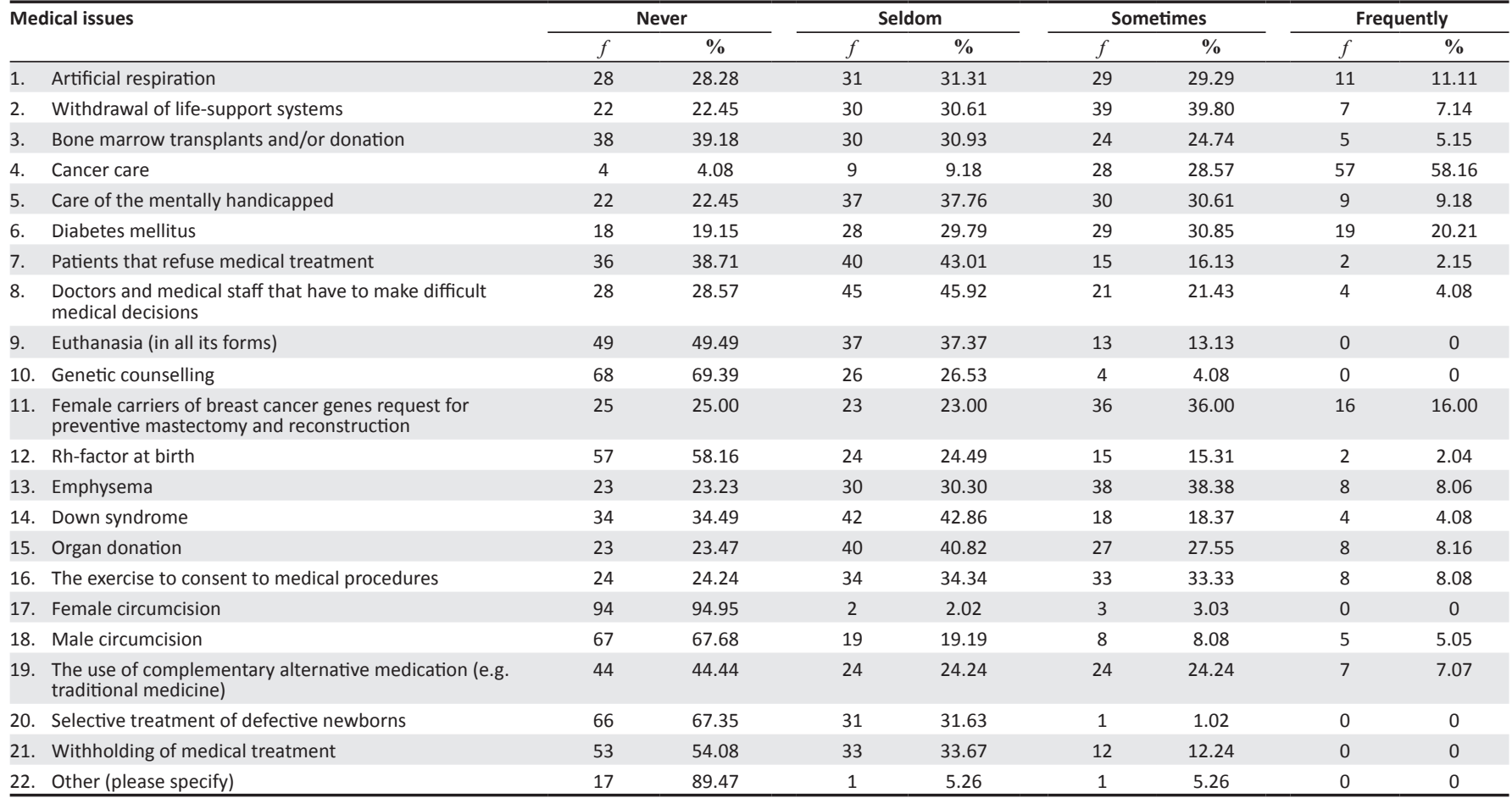

$f$, frequency. 
TABLE 4: The frequency with which ministers were confronted with ethical issues regarding agricultural and environmental technologies.

\begin{tabular}{|c|c|c|c|c|c|c|c|c|c|}
\hline \multicolumn{2}{|r|}{ Agricultural and environmental technologies } & \multicolumn{2}{|c|}{ Never } & \multicolumn{2}{|c|}{ Seldom } & \multicolumn{2}{|c|}{ Sometimes } & \multicolumn{2}{|c|}{ Frequently } \\
\hline & & $f$ & $\%$ & $f$ & $\%$ & $f$ & $\%$ & $f$ & $\%$ \\
\hline 1. & Agricultural pesticides & 41 & 42.71 & 29 & 30.21 & 17 & 17.71 & 9 & 9.38 \\
\hline 2. & $\begin{array}{l}\text { Bio-engineered fruit and vegetables (such as long-life } \\
\text { products) }\end{array}$ & 46 & 46.46 & 31 & 31.31 & 18 & 18.18 & 4 & 4.04 \\
\hline 3. & Genetically modified organisms for production of medicine & 68 & 70.10 & 20 & 20.62 & 6 & 6.19 & 3 & 3.09 \\
\hline 4. & Pollution & 17 & 17.35 & 21 & 21.43 & 35 & 35.71 & 25 & 25.51 \\
\hline 5. & Nuclear power & 56 & 56.57 & 27 & 27.27 & 12 & 12.12 & 4 & 4.04 \\
\hline 7. & Soil erosion & 41 & 41.84 & 27 & 27.55 & 19 & 19.39 & 11 & 11.22 \\
\hline 8. & Farming activities that influence the greenhouse effect & 47 & 47.47 & 30 & 30.30 & 17 & 17.17 & 5 & 5.05 \\
\hline 9. & Other (please specify) & 18 & 100 & 0 & 0 & 0 & 0 & 0 & 0 \\
\hline
\end{tabular}

$f$, frequency.

TABLE 5: Ministers' responses to certain value judgements.

\begin{tabular}{|c|c|c|c|c|c|}
\hline \multicolumn{2}{|c|}{ Value judgement } & \multicolumn{2}{|c|}{ Yes } & \multicolumn{2}{|c|}{ No } \\
\hline 1. & Do you think it is important for ministers of religion to have knowledge of technological and scientific research? & $\frac{f}{97}$ & $\begin{array}{c}\% \\
97.98\end{array}$ & $\frac{f}{2}$ & $\begin{array}{c}\% \\
2.02\end{array}$ \\
\hline 2. & $\begin{array}{l}\text { It is the individual who must decide and whatever authority one employs in the decision is the choice and responsibility } \\
\text { of the individual alone. }\end{array}$ & 16 & 16.33 & 82 & 83.67 \\
\hline 3. & $\begin{array}{l}\text { I know where to find genetic counselling and genetic services for those congregation members who may profit from } \\
\text { such counselling services. }\end{array}$ & 49 & 50 & 49 & 50 \\
\hline 4. & Do you think scientific knowledge should have an influence on our ethical reasoning? & 93 & 93.94 & 6 & 6.06 \\
\hline 6. & If someone is a carrier of a defective gene or has a genetic disease, the person's fiancé or fiancée deserves to know. & 96 & 97.96 & 2 & 2.04 \\
\hline 7. & If someone is HIV positive, the person's fiancé or fiancée deserves to know. & 98 & 98.99 & 1 & 1.01 \\
\hline 8. & $\begin{array}{l}\text { If tests show that an individual is likely to get a serious or fatal disease later in life, would you advise them to undergo } \\
\text { genetic therapy to have these genes corrected before symptoms appear? }\end{array}$ & 59 & 61.46 & 37 & 38.54 \\
\hline 9. & I often engage in discussions with professionals such as doctors and nurses about bioethical issues. & 19 & 19.59 & 78 & 80.41 \\
\hline 10. & I think the Reformed Churches in South Africa contribute significantly to guidance about bioethical issues. & 20 & 20.62 & 77 & 79.38 \\
\hline
\end{tabular}

$f$, frequency.

strongly', 'disagree somewhat', 'agree somewhat' or 'strongly agree' with the statements provided (Table 6).

\section{Questionnaire Section E}

This section was included in an attempt to establish the theoretical basis on which ministers build their decisionmaking arguments. Table 7 indicates the preferred theoretical basis that was deduced from responses to several statements which clearly indicate the theoretical preference of each respondent. Some of the types of statements to which they should have indicated a 'yes' or a 'no' are:

- All moral rules must be in accordance with the teachings of the Bible.

- All moral rules must be in accordance with the will of God.

- Questions such as 'What is good?' and 'What has to be done?' should be asked first.

- The consequences of my moral actions are the most important factor.

- Human conduct is determined by those socio-moral rules that can pass the test of utility (usefulness).

- Moral goodness is determined by calculation on the basis of what benefits the greater number of persons.

- Ultimate good is the greatest happiness for the greatest number of people.

- In dealing with bioethical issues, the focus must be on character traits, personal commitments and community traditions.
- In dealing with bioethical issues, the focus must be on the conditions humans need to excel and flourish.

- In dealing with bioethical issues, listen to your inner 'instinct'.

The importance of the different disciplines in contributing to the formation of a metaphysical background to the ministers' ethical theory is indicated in Table 8.

\section{Questionnaire Section F}

In this section, each minister was asked to indicate what he thinks he can contribute to the resolution of bioethical dilemmas. This open-ended question has been analysed by categorising the data using categories that are generated, at least in part, inductively (i.e. derived directly from the data) (Jacoby \& Siminoff 2008:40). A total of 73 ministers responded to the open-ended question.

\section{Study of Scriptures}

The majority of respondents indicated that they must rely on the Scriptures and sound exegesis for guidelines and principles in dealing with bioethical dilemmas. The need to remain answerable to God for actions and choices is a prominent motif in many responses. This corresponds with the $95 \%$ of respondents who indicated the importance of Scripture in practicing pastoral care. 


\begin{tabular}{|c|c|c|c|c|c|c|c|c|c|}
\hline \multicolumn{2}{|c|}{ Leadership issues } & \multicolumn{2}{|c|}{ Disagree strongly } & \multicolumn{2}{|c|}{ Disagree somewhat } & \multicolumn{2}{|c|}{ Agree somewhat } & \multicolumn{2}{|c|}{ Strongly agree } \\
\hline 1. & $\begin{array}{l}\text { Technology unchallenged by Christian ethical norms can be } \\
\text { as potentially destructive as it may be beneficial. }\end{array}$ & $\begin{array}{l}f \\
1\end{array}$ & \begin{tabular}{c|c|}
$\%$ \\
1.02
\end{tabular} & $\begin{array}{l}f \\
4\end{array}$ & \begin{tabular}{c|c}
$\%$ \\
4.08
\end{tabular} & $\begin{array}{c}f \\
28\end{array}$ & \begin{tabular}{c|}
$\%$ \\
28.57
\end{tabular} & $\begin{array}{c}f \\
65\end{array}$ & $\begin{array}{c}\% \\
66.33\end{array}$ \\
\hline 2. & $\begin{array}{l}\text { Bioethical issues should be approached through } \\
\text { interdisciplinary enquiry and well-developed educational } \\
\text { programmes to assist ministers in thoughtful decision- } \\
\text { making. }\end{array}$ & 0 & 0 & 3 & 3.09 & 22 & 22.68 & 25 & 25.77 \\
\hline 3. & $\begin{array}{l}\text { Congregation members have the right to know what the } \\
\text { official viewpoint of the RCSA is about certain bioethical } \\
\text { issues. }\end{array}$ & 1 & 1.02 & 1 & 1.02 & 17 & 17.35 & 79 & 80.61 \\
\hline 4. & $\begin{array}{l}\text { It is the ministers' responsibility to practice moral teaching } \\
\text { from the pulpit. }\end{array}$ & 2 & 2.04 & 8 & 8.16 & 39 & 39.80 & 49 & 50.00 \\
\hline 5. & $\begin{array}{l}\text { The purpose of the homily is not, in the first instance, to } \\
\text { teach moral principles. }\end{array}$ & 10 & 10.10 & 19 & 19.19 & 41 & 41.41 & 29 & 29.29 \\
\hline 6. & $\begin{array}{l}\text { Congregation members should not rely on the minister } \\
\text { alone for guidance in bioethical issues. }\end{array}$ & 1 & 1.01 & 7 & 7.07 & 38 & 38.38 & 53 & 53.54 \\
\hline 7. & $\begin{array}{l}\text { Congregation members do not have to ask ministers } \\
\text { questions on bioethical issues. }\end{array}$ & 24 & 24.24 & 51 & 51.52 & 16 & 16.16 & 8 & 8.08 \\
\hline 8. & $\begin{array}{l}\text { Ministers should guide congregation members on } \\
\text { bioethical issues. }\end{array}$ & 2 & 2.02 & 0 & 0 & 47 & 47.47 & 50 & 50.51 \\
\hline 9. & $\begin{array}{l}\text { When dealing with bioethical issues, ministers should take } \\
\text { cultural backgrounds into consideration. }\end{array}$ & 9 & 9.09 & 9 & 9.09 & 53 & 53.54 & 28 & 28.28 \\
\hline 10. & $\begin{array}{l}\text { It is important to offer my congregation instructive } \\
\text { programmes designed to help them make moral decisions } \\
\text { with respect to bioethical issues. }\end{array}$ & 1 & 1.01 & 12 & 12.12 & 47 & 47.47 & 39 & 39.39 \\
\hline 11. & $\begin{array}{l}\text { Extended family members should be involved in decision- } \\
\text { making processes. }\end{array}$ & 3 & 3.03 & 13 & 13.13 & 69 & 69.70 & 14 & 14.14 \\
\hline 12. & $\begin{array}{l}\text { I am sensitive to the diversity of cultural backgrounds } \\
\text { within the immediate neighbouring community of my } \\
\text { congregation. }\end{array}$ & 3 & 3.06 & 5 & 5.10 & 48 & 48.98 & 42 & 42.86 \\
\hline 13. & $\begin{array}{l}\text { It is important to integrate faith into the decision-making } \\
\text { process. }\end{array}$ & 1 & 1.01 & 0 & 0 & 9 & 9.09 & 89 & 89.90 \\
\hline 14. & I can make ethical decisions based on reason alone. & 56 & 56.57 & 29 & 29.29 & 10 & 10.10 & 4 & 4.04 \\
\hline 15. & $\begin{array}{l}\text { Christian Theology alone provides the fundamental } \\
\text { framework in which ethical discussion can be made. }\end{array}$ & 9 & 9.28 & 21 & 21.65 & 38 & 38.18 & 29 & 29.90 \\
\hline 16. & $\begin{array}{l}\text { Clergy have the responsibility of informing their } \\
\text { congregation of genetic issues that could affect future } \\
\text { decisions by these congregation members regarding } \\
\text { marriage and having a family. }\end{array}$ & 5 & 5.10 & 19 & 19.39 & 52 & 52.04 & 23 & 23.47 \\
\hline 17. & $\begin{array}{l}\text { Ministers should obtain clear and current communications } \\
\text { from professionals about progress in bioethical } \\
\text { technologies. }\end{array}$ & 4 & 4.04 & 8 & 8.08 & 50 & 50.51 & 37 & 37.37 \\
\hline 18. & $\begin{array}{l}\text { Ministers have to be armed with an appreciation for ethical } \\
\text { theory. }\end{array}$ & 0 & 0 & 2 & 2.02 & 38 & 38.38 & 59 & 59.60 \\
\hline 19. & $\begin{array}{l}\text { Ministers should take an active part in their communities } \\
\text { by serving on ethical commissions and panels. }\end{array}$ & 6 & 6.12 & 18 & 18.37 & 49 & 50 & 25 & 25.51 \\
\hline
\end{tabular}

$f$, frequency.

\section{Training}

There is an outspoken desire that, to stay abreast of new bioethical developments, ministers would attend workshops, courses and seminars presented by specialists in various related disciplines (i.e. medical, legal, bioethical and theological). One respondent suggested that guidance is required especially for ministers who specialise in Bioethics.

\section{Personal research}

Developing a sound personal knowledge base and taking cognisance of recent developments also featured strongly in the open-ended responses.

\section{Pastoral guidance}

Offering Bible studies, leading discussion groups, presenting sermons and counselling congregants during personal visits on discerning God's guidelines in Scripture will empower congregants to deal with these issues against the background of God's providential plan. Knowing and listening to congregants' problems and concerns in these areas would also help them to make decisions according to the will of God, thereby adhering to biblical and ethical principles.

\section{Societal involvement}

Respondents also expressed the importance of knowing the context of the Church in society and, consequently, to serve both the Church and broader communities by becoming involved in discussions with professionals dealing in the field, as well as by making a contribution to ethics committees.

\section{Other issues}

A number of other issues were also raised by some respondents including, (1) ministers should teach congregants to be answerable to God for all activities and choices, (2) there is a need for a stronger interaction between various disciplines (cf. Table 8) and (3) specialised support should be available for ministers who may require advice on dealing with bioethical dilemmas in their congregations. 
TABLE 7: Ministers' preferred theoretical basis when dealing with ethical issues.

\begin{tabular}{ll}
\hline Ethics & $\mathbf{\%}$ \\
\hline Deontological ethics & 99 \\
Teleological ethics & 29 \\
Utilitarian ethics & 21 \\
Virtue ethics & 39 \\
\hline
\end{tabular}

\section{Discussion and conclusion}

The present study set out to examine three questions by means of a survey amongst ministers serving within the Reformed Churches in South Africa. The first question concerned assessing the bioethical dilemmas ministers encounter in their work environment and to determine how often they are confronted with these dilemmas. The data demonstrated that the respondents are confronted by a vast number of bioethical issues in the congregations they serve (cf. Tables 2, 3 and 4). When considering the distribution and frequency of the various issues indicated in the questionnaire, it confirms the need to assume a more holistic approach towards bioethics than is presently the case. It also indicates the need for ministers to be well equipped to deal with these dilemmas in a proper way.

When considering which value judgements they make when reflecting on bioethical dilemmas and pastoral moral leadership (cf. Tables 5 and 6), a very interesting phenomenon occurs. Although indicating a significant reliance on Scripture in the open-ended ${ }^{6}$ question (Section F), the need for other forms of knowledge, viz. technology, scientific research, medical facts and an engagement with other professionals in the field of Bioethics is strongly

6.Advantage was taken with the open-ended question in order to not only evaluate bioethical assumptions, but also to be able to inform meta-theoretical practices, how to use theoretical knowledge and how to evaluate bioethics-related processes in the ministry (cf. Jacoby \& Siminoff 2008:41-42). emphasised. A high percentage of respondents indicated that it is not viable for individuals to take responsibility for making decisions and this coincides with the need for ministers to become more involved in pastoral guidance, as indicated in the open-ended question. The RCSA must take note of the fact that almost $80 \%$ of the respondents indicate that the Church does not contribute significantly to guidance about bioethical issues.

The third question deals with the theoretical and/or theological sources or resources ministers call upon and their reflection on these difficult situations when counselling members of their congregation on bioethical dilemmas (cf. Tables 7, 8 and 9). Interestingly, almost all of the respondents indicate a deontological theoretical basis for ethical reflection. Another interesting aspect of the data presented in Table 8 is that only $52 \%$ responded to Theology as a discipline involved in bioethical reflection. A possible explanation for this phenomenon could be that they do not regard Theology as a socially relevant discipline, but rather one that only has relevance for the domain of spirituality. Note, however, that this does not correspond with the results of Question 15 in Table 6, in which Christian Theology is considered to be the fundamental framework for ethical discussion. Further research is therefore necessary to assess this discrepancy.

The author is of the opinion that a lack of moral consensus often stems from not understanding ethical paradigms and not having the knowledge of ethical theories which form the basis of ethical decision-making. This view is also underpinned by Van der Merwe (2002:17-19) when he argues that 'knowledge of ethical theories is a great help in identifying one's own ethical identity and in understanding people with apposing ethical views'. Taking into consideration the fact that the data reflect the eagerness of a large number of

TABLE 8: The degree to which various disciplines played a role in establishing ministers' ethical theory.

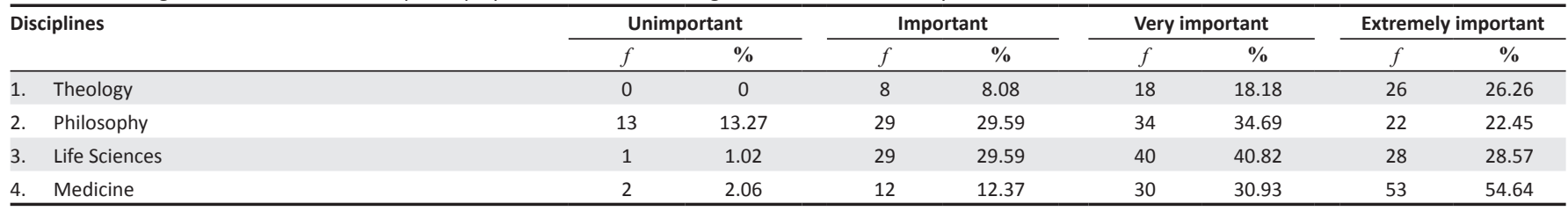

$f$, frequency.

TABLE 9: The degree to which various concepts were necessary for practicing pastoral care.

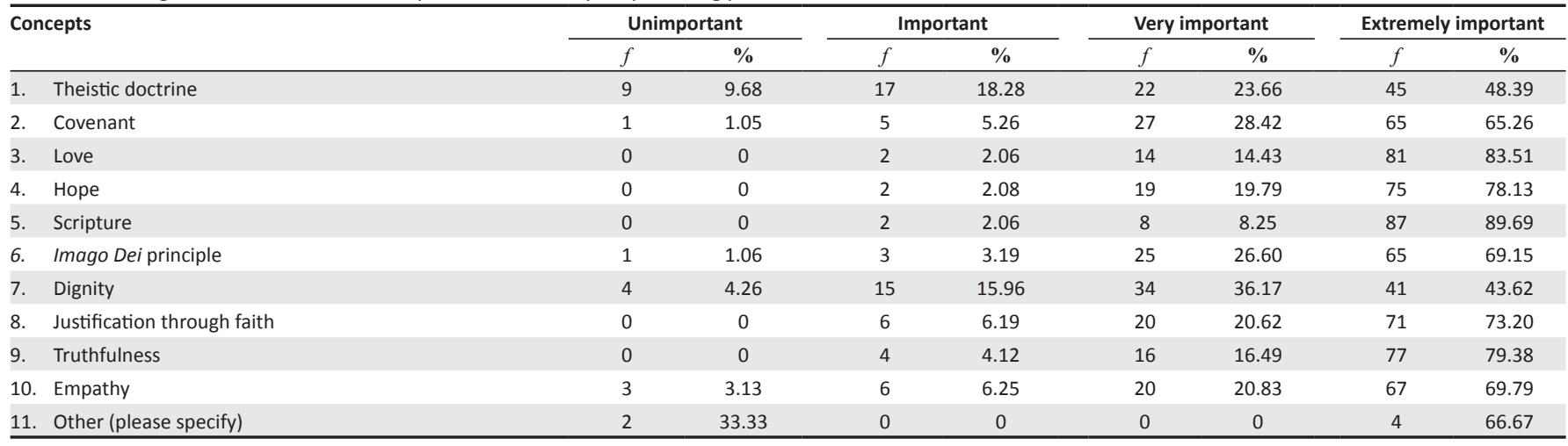

$f$, frequency. 
ministers to learn more about bioethical issues, it is clear that they are of opinion that additional and different educational experiences ${ }^{7}$ would have prepared them more adequately for providing moral leadership with regard to bioethical issues; they understand the need for the interdisciplinary nature of Bioethics in order to provide pastoral care.

This research project has underlined the need for the integration of empirical research in bioethical reflection and decision-making. This will provide better and more workable solutions for the practical reality of the interdisciplinary nature of rational bioethical problem-solving. The emphasis is thus on a form of integrated empirical ethics (cf. Molewijk et al. 2004), where ethical theories and empirical data are integrated in order to arrive at a normative conclusion with respect to specific bioethical practices.

It can be concluded that recent advancements in biotechnology cannot be ignored or dealt with in a piecemeal and impressionistic fashion, either by the RCSA or its ministers, for much longer. In order to deal with this problem, they must look for clarity and analyse the principles and underlying theories that guide, or should guide, their decision-making and pastoral care in these situations. The findings highlight the need not only for appropriate courses in Bioethics during ministers' initial theological training, but also the need to keep the debate alive by offering workshops, seminars and short courses for practicing ministers in order to enhance awareness and allay fears and uncertainties in this very dynamic and morally challenging field of human and scientific endeavour.

\section{Acknowledgements}

The author would like to thank her promoter, Prof. J.M. (Koos) Vorster and co-promoter, Prof. H.J.M (Hans) van Deventer for useful comments during different stages of this research project.

\section{Competing interests}

The author declares the she has no financial or personal relationship(s) which may have inappropriately influenced her in writing this article.

\section{References}

Akhtar, M.N., 2002, 'Ethics in public health', American Journal of Public Health 92 1056. http://dx.doi.org/10.2105/AJPH.92.7.1056, PMCid:3222277

Asai, A., Nakayama, T. \& Naito, M., 2003, 'Ethics in questionnaire-based research', Eubios Journal of Asian and International Bioethics 13, 147-151.

Babbie, E.A. \& Mouton, J., 2001, The practice of social research, Oxford University Press, Oxford.

Borry, P., Schotsmans, P. \& Dierickx, K., 2004, 'What is the role of empirical research in bioethical reflection and decision-making? An ethical analysis' Medicine, Health Care and Philosophy 7(1), 41-53. http://dx.doi.org/10.1023/ B:MHEP.0000021844.57115.9d

Borry, P., Schotsman, P. \& Dierickx, K., 2005, 'The birth of the empirical turn in Bioethics', Bioethics 19(1), 49-71. http://dx.doi.org/10.1111/j.1467-8519.2005.00424.x, PMid:15812972

7 .In a recent study on the experiences and needs of pastoral counsellors and ministers (Human \& Müller 2009), the need for in-depth practical training at university and the value of turning to literature regarding all ethical dilemmas was emphasised, amongst others.
Bosk, C.L., 1999, 'Professional ethicist available: Logical, secular, friendly', Daedalus $128,47-68$.

Breakwell, G.M., 2003, 'Interviewing', in G.M. Breakwell, S. Hammond \& C. Fife-Schaw (eds.), Research methods in psychology, pp. 239-250, SAGE publications, London.

Burns, N. \& Grove, S.K., 1997, The practice of nursing research: Conduct, critique and utilisation, WB Saunders, Philadelphia, PA.

Cole-Turner, R., 2006, 'Biotechnology and the religion-science discussion', in P. Clayton \& Z. Simpson (eds.), The Oxford handbook of religion and science, pp. 929-944, Oxford University Press, Oxford. http://dx.doi.org/10.1093/ oxfordhb/9780199279272.003.0055

Coughlin, M.D. \& Watts, J., 1993, 'A descriptive study of healthcare ethics consultants in Canada: Results of a national survey', HEC Forum: An Interdisciplinary Journal on Hospitals' Ethical and Legal Issues 5(3), 144-164.

Creswell, J.W., 2003, Research design: Qualitative, quantitative, and mixed method approaches, SAGE publications, London.

Creswell, J.W. \& Plano Clark, V.L., 2007, Designing and conducting mixed method research, SAGE publications, Thousand Oaks, CA.

Cross, W.O., 1977, 'Toward a context for the ethics of abortion', Anglican Theological Review 59(2), 212-220.

De Roubaix, J.A.M., 2002, "n Postmoderne uitdaging aan die "paradigmale biomediese etiek model" met verwysing na kompleksiteits-teorie', MA verhandeling, Departement Filosofie, Stellenbosch Universiteit.

De Lange, M.C., 2009, 'Exploring interdisciplinarity: A theoretical consideration of Bioethics at the interface between Theology, Philosophy and Life Sciences', The Journal of Transdisciplinarity Research in Southern Africa 5(2), 191-216.

De Vos, A.S., Strydom, H., Fouche, C.B. \& Delport, C.S.L., 2005, Research at grass roots: For the social sciences and human service professions, 3rd edn., Van Schaik, Pretoria.

Field, A., 2005, Discovering statistics using SPSS, 2nd edn., SAGE publications, London.

Fletcher, J.C., 1981, 'Clergy involvement: Relating practice to principle', in C. Baumiller (ed.), Genetic decision making and pastoral care, pp. 38F, 38K-38L, 38P, March of Dimes Birth Defects Foundation, New York, NY.

Fox, E., Myers, S. \& Pearlman, R.A., 2007, 'Ethics consultation in United States hospitals: A national survey', The American Journal of Bioethics 7(2), 13-25. http://dx.doi.org/10.1080/15265160701193575, PMid:17366182

Fry, H.L., 2005, 'The application of virtue ethics to the practice of counselling', PhD thesis, Department of Psychology, The Ohio State University.

Gereformeerde Kerke in Suid-Afrika, 2009, Die Almanak van die Gereformeerde Kerke in Suid Afrika vir die jaar 2009, Die Almanak, jg. 136, GKSA, Administratiewe Buro, Potchefstroom.

Goldenberg, M.J., 2005, 'Evidence-based ethics? On evidence-based practice and the "empirical turn" from normative bioethics', BMC Medical Ethics 6(11), viewed 30 July 2009, from http://www.biomedcentral.com/1472-6939/6/11

Grosser, M.M., 1999, 'Die rol van koöperatiewe leer in die ondersteuning van ' $n$ denkontwikkelingsbenadering', PhD-verhandeling, Department Opvoedkunde, Vista Universiteit.

Grundstein-Amado, R., 1991, 'An integrative model of clinical-ethical decision-making', Theoretical Medicine 12, 157-170. http://dx.doi.org/10.1007/BF00489796, PMid:1896954

Guba, E.G. \& Lincoln, Y.S., 1989, Fourth generation evaluation, SAGE publication, Newbury Park.

Gushee, D.P., 2003, 'Ethical method in Christian bioethics: Mapping the terrain', viewed 22 January 2008, from http//www.conscincelaws.org/ExaminingConcienceEthical/Ethical41.html

Gustafson, J.M., 1983, Ethics from a Theocentric perspective: Theology and Ethics, vol. 1, University of Chicago Press, Chicago, IL.

Hanford, J., 2006, 'The pastor and Bioethics', Pastoral Psychology 55, 175-182. http:// dx.doi.org/10.1007/s11089-006-0044-z

Holloway, I., 1997, Basic concepts for qualitative research, Blackwell, Oxford.

Human, H. \& Müller, J.C., 2009, 'Doing the job well: Looking at the role of ethics and ethical dilemmas in the work of pastoral counsellors', Practical Theology in South Africa 24(2), 161-179.

Jacoby, L. \& Siminoff, L.A., 2008, Empirical methods for Bioethics: A primer, Elsevier, Amsterdam.

Keenan, J.F., 2005, 'Notes on moral Theology: Ethics and the crisis in the church', Theological Studies 66, 117-136.

Kumar, R., 2005, Research methodology: A step-by-step guide for beginners, 2nd edn., SAGE Publications, London.

Lategan, L.O.K., 2007, 'Etiek in navorsing: 'n Voorgestelde raamwerk vir waardegedrewe navorsing', Tydskrif vir Christelike Wetenskap 43(3/4), 235-251.

Lategan, L.O.K., 2008, 'Identifying critical indicators to deal with research integrity', Journal of Christian Scholarship 44(1/2), 103-120.

McMillan, R.C., 1986, 'Bioethical decision-making: Where the buck stops', Perspectives in Religious Studies 13(2), 125-136.

McMinn, M.R. \& Runner, S.J., 2004, 'Why should Christian counsellors care about ethics research?', Christian Counselling Today 12(4), 56-59.

Mertens, T.R., Hendrix, J.R. \& Gordon, L.M., 1986, 'Indiana clergy: A survey of their human genetics/bioethics educational needs', The Journal of Pastoral Care 40(1), 43-55. PMid:11645584 
Molewijk, B., Stiggelbout, A.M., Otten, W., Dupuis, H.M. \& Kievit, J., 2004, 'Scientific contribution. Empirical data and moral theory. A plea for integrated empirical ethics', Medicine, Health Care and Philosophy 7(1), 55-69. http://dx.doi. ethics', Medicine, Health Care and Philoso
org/10.1023/B:MHEP.0000021848.75590.b0

Neuman, W.L., 1994, Social research methods: Qualitative and quantitative approaches, 5th edn., Allyn\&Bacon, Boston, MA.

Neuman, W.L., 1997, Social research methods: Qualitative and quantitative approaches, Allyn \& Bacon, Boston, MA.

Orr, B.J., 1992, 'A comparative study in normative ethics: Perceptual differences of educators, physicians, and ethicists concerning life and death issues', PhD thesis, Department of Education, The University of Tennessee.

Rosnow, R.L. \& Rosenthal, R., 1996, Beginning behavioural research: A conceptual primer, Prentice-Hall, Upper Saddle River, NJ.

SAS Institute Inc., 2003, The SAS System for Windows, computer software, Release 9.1 TS Level 1M3, SAS Institute Inc., Cary, NC.

Schotsmans, P.T., 2009, 'Christian Bioethics in Europe: In defence against reductionis influences from the United States', Christian Bioethics 0, 1-14.

Seitz, M.J., Perkins, I., Marcin, R.B. \& Hogan, C., 2004, 'The role of the priest in bioethical decision-making', The National Catholic Bioethics Quarterly Winter 681-689. PMid:15658025

Simmonds, A.L., 1994, 'The Chaplains role in bioethical decision-making', Healthcare Management Forum 7(4), 5-10. http://dx.doi.org/10.1016/S0840 4704(10)61072-1
Steyn, A.G.W., Smit, C.F., Du Toit, S.H.C. \& Strasheim, C., 2000, 'Statistiek, 'n middel tot 'n doel', Moderne statistiek vir die praktyk, pp. 1-5, Van Schaik, Pretoria.

Sudman, S. \& Bradburn, N.M., 1983, Asking questions, Jossey-Bass, London.

Sugarman, J. \& Sulmasy, D.P. (eds.), 2001, Methods in medical ethics, Georgetown University Press, Washington DC.

Sutton, A., 2008, Christian Bioethics: A guide for the perplexed, T\&T Clark, London.

Taylor, G., 1996, Student's writing guide for the arts and social sciences, Cambridge University Press, Cambridge.

Thietart, R.A., 2001, Doing management research: A comprehensive guide, SAGE publications, London.

Thomasma, D.C., 1985, 'Empirical methodology in medical ethics', Journal of the American Geriatrics Society 5, 313-314.

Thomasma, D.C., 2001, 'Ethic consultation rules: A comment on George J. Agich', The American Journal of Bioethics 1(4), 46-47. http://dx.doi org/10.1162/152651601317139405, PMid:11954638

Tulsky, J.A. \& Fox, E., 1996, 'Evaluation ethics consultation: Framing the questions', Journal of Clinical Ethics 7, 109-115. PMid:8889885

Van Der Merwe, J.C., 2002, 'Making ethics work', in L. Lategan \& P. Le Roux (eds.), Business Ethics, pp. 16-23, Teskor, Bloemfontein.

Wang, K.H., Katz, R.V. \& Howard, D., 2007, 'Bioethical issues in biostatistical consulting: Development of a survey', Psychological Reports 100(1), 191-194. http://dx.doi org/10.2466/pr0.100.1.191-194, PMid:17451024

Zussman, R., 2000, 'The contributions of sociology to medical ethics', Hastings Centre Reports 30, 7-11. http://dx.doi.org/10.2307/3527988, PMid:10742940 